\title{
Maximum Torque per Ampere Strategy in IPM Drives for Electric Vehicles
}

\author{
Osman Emre ÖzÇiFLİKÇía, Mikail KOÇ ${ }^{b}$, Serkan BAHÇECíc \\ ${ }^{\mathrm{a}, \mathrm{b}}$ Kırşehir Ahi Evran University, Engineering and Architecture Faculty, Electrical and Electronics \\ Engineering Department, Kırşehir/ Turkey, \\ ${ }^{c}$ Erciyes University, Engineering Faculty, Electrical and Electronics Engineering Department, \\ Kayseri/Turkey \\ osman.ozciflikci@ahievran.edu.tr
}

Received/Geliş: 04.05.2021

Accepted/Kabul: 25.07.2021

\begin{abstract}
Permanent magnet synchronous motors (PMSM) are generally known for their type whose magnets are located on the rotor surface and this motor type, which is called surface mounted permanent magnet synchronous motors (SPM), produces magnet based torque. Based on torque equations, since there is only q-axis current and value of magnetic flux linkage, the d-axis current is kept at 0 and the torque is maximized and controlled, which is called $I_{d}=0$ control technique. However, reluctance torque is produced in interior mounted permanent magnet synchronous motors (IPM) due to the inductance difference caused by the saliency in the rotors and by controlling the reluctance torque correctly, the efficiency of motor increases. For this reason, maximum torque per ampere (MTPA) strategy is applied to perform torque control efficiently in IPMs. In this study, the difference between the efficiency values was observed by simulating torque control in IPMs with the MTPA strategy instead of the conventionally used $I_{d}=0$ control technique. As a result of the simulations, using the MTPA strategy instead of the conventional vector control technique in the drivers of the IPMs used in electric vehicle applications increases the efficiency of the system and extends drive range capacity by using the battery more efficiently.
\end{abstract}

Keywords: IPM, MTPA, Torque Control

\section{Elektrikli Araçlar İçin GMSM Sürücülerinde Akım Başına Maksimum Tork Stratejisi}

\begin{abstract}
Öz: Kalıcı mıknatıslı senkron motorlar (KMSM), genellikle mıknatısları rotor yüzeyinde bulunan çeşidi ile bilinir ve yüzey mıknatıslı senkron motorlar (YMSM) olarak adlandırılan bu motor çeşidi rotor yüzeyinde bulunan mıknatıs tabanlı tork üretirler. Tork eşitliklerinde sadece q-eksen akımının ve sabit mıknatıslardaki akı değerinin olmasından dolayı d-eksen akımı 0 değerinde tutularak tork maksimize edilir ve kontrolü sağlanır ki bu kontrol tekniğine $I_{d}=0$ kontrol tekniği denir. Fakat gömülü mıknatıslı senkron motorlarda (GMSM) rotorlarındaki çıkıntıdan kaynaklanan endüktans farkından dolayı relüktans tork üretilir ve relüktans torkunun doğru bir şekilde kontrol edilmesiyle motor verimi yükselmektedir. Bu sebeple GMSM'lerde tork kontrolünün verimli şekilde gerçekleştirilebilmesi için akım başına maksimum tork (ABMT) stratejisi uygulanmaktadır. Bu çalışmada GMSM'lerde tork kontrolünün konvansiyonel olarak kullanılan $I_{d}=0$ kontrol tekniği yerine ABMT stratejisi ile simülasyonu gerçekleştirilerek verim değerleri arasındaki fark gözlenmiştir. Baz hızın altındaki hız değerlerinde tork kontrolünün verimli bir şekilde gerçekleştirildiği simülasyon sonuçları ile doğrulanmıştır. Simülasyonlar sonucunda elektrikli araç uygulamalarında kullanılan GMSM'lerin sürücülerinde konvansiyonel vektör kontrol tekniği yerine ABMT stratejisinin kullanılması sistemin verimini artırmakta ve bataryayı daha verimli kullanarak daha uzun menzil kapasitesi sağlamaktadır.
\end{abstract}

Anahtar Kelimeler: ABMT, GMSM, Tork Kontrolü 


\section{Introduction}

Environmental problems such as global warming, acid rain, depletion of the ozone layer have revealed the necessity of reducing the carbon dioxide emissions in the world. The carbon dioxide emission rates in commercial, residential, transportation and industry are $\% 15, \% 19, \% 32$ and $\% 34$, respectively [1]. To overcome these problems, it is necessary to increase the use of renewable energy sources worldwide. The carbon dioxide emission in the transportation is at a considerable level, and its level can be reduced by increasing the use of electric vehicles as they can use renewable energy sources [2-4].

Permanent magnet synchronous motors (PMSM) are commonly used at different application area due to their superior features such as high efficiency, low acoustic noise, and small volume [5]. For these reasons, PMSMs have been preferred commonly in electric vehicle technology since 2010 [6]. In addition, from the results of [7], the authors conclude that PMSMs are more suitable for electric and hybrid vehicles. Hence, PMSMs and their control systems are an extremely important research subject for electric vehicle technology.

PMSMs can be divided into two groups as surface mounted permanent magnet (SPM) and interior mounted permanent magnet (IPM) according to the magnet placement in the rotors [8]. Due to the non-salient rotor structure of SPMs, when the motor is modelled in d- and q- axes, there is no inductance difference between the two axes. For this reason, they only produce the torque that the permanent magnets in the rotor can produce according to the magnetic flux linkage value, and when the motor is controlled using the field-oriented control (FOC) technique, torque control can be performed with only the q-axis current so this control technique is commonly known as $I_{d}=0$ control technique [9-11]. However, since the inductance values in the d- and q-axes are different from each other in IPMs, they can produce reluctance torque as well as the torque production based on the magnets [12]. The torque production can be increased with the correct utilization of the reluctance torque, and the motor capacity can be used more efficiently. The correct use of the reluctance torque is achieved by producing the appropriate current values to determine the optimum operating point for the system from the reference torque value. The control strategy in which the reluctance torque is controlled correctly is called as the maximum torque per ampere (MTPA) strategy.

Since there is no reluctance torque in SPMs, the d-axis current has no effect on the torque generation and the $I_{d}=0$ control technique is the realization of torque control with the q-axis current, which corresponds to the armature current in DC motors. In $I_{d}=0$ control technique, the d-axis current is kept at 0 to maximize the torque production. In fact, the use of the $I_{d}=0$ control technique means that the MTPA strategy is applied to SPMs [11], as the torque value changes proportionally to the qaxis current, so the control operation is provided on an axis and it is a simpler system compared to the MTPA strategy of IPMs. In the MTPA strategy for IPM drives, the reference current values generated from the torque depend on both axes, so it is more complicated than the $I_{d}=0$ control technique.

The purpose of applying the MTPA strategy is to produce the current values that will provide the optimum operating point of the IPMs from the torque value requested from the system. There are various methods to find the MTPA trajectory in the literature [13], by testing the motor in suitable test environments and obtaining the current values required to operate at the optimum point according to the reference torque value, using pre-prepared look-up tables [14-16], signal processing methods through real signal injection [17], virtual signal injection due to the fact that real signal injection brings extra losses to the system $[18,19]$, and trajectory is obtained by solving non-linear equations in order to generate reference currents from the torque value requested from the system with 
mathematical equations [20-22]. In this paper, MTPA points will be determined by the solution of non-linear equations with mathematical method and will be applied to the drive system.

In this study, it has been shown that the commonly used $I_{d}=0$ control technique, due to its simplicity, is not suitable for each type of PMSM and does not provide maximum efficiency. Although the $I_{d}=0$ control technique for SPMs is the most appropriate control technique in the constant torque region, the efficiency value increases considerably by using the MTPA strategy for IPMs. With the use of the MTPA strategy in IPM drives for electric vehicle applications, it has been confirmed by the simulation results that the stored energy in the battery can be used more efficiently. The demanded torque value can be produced with a minimized current magnitude.

\section{Mathematical Expressions}

\subsection{IPM Model and MTPA Equations}

The motor model and control algorithm are expressed in dq-axes using coordinate transformations. After applying Clarke and Park transformations to three phase motor equations, the motor voltage equations in the dq-axis are given by (1) and (2). IPM torque equation is given by (3). The reluctance torque and torque produced by the magnets are given by (4) and (5).

$$
\begin{gathered}
V_{d}=R_{s} * I_{d}+L_{d} * \frac{d I_{d}}{d t}-w_{e} * L_{q} * I_{q} \\
V_{q}=R_{S} * I_{q}+L_{q} * \frac{d I_{q}}{d t}+w_{e} * L_{d} * I_{d}+w_{e} * \Psi_{m} \\
T_{e}=\frac{3 * p}{2} *\left(I_{q} * \Psi_{m}+\left(L_{d}-L_{q}\right) * I_{d} * I_{q}\right) \\
T_{e}^{\text {Magnet }}=\frac{3 * p}{2} *\left(I_{q} * \Psi_{m}\right) \\
\text { Reluctance } \left.=\frac{3 * p}{2} *\left(L_{d}-L_{q}\right)^{*} I_{d} * I_{q}\right)
\end{gathered}
$$

$V_{d}$ and $V_{q}$ are the direct and quadrature axis voltages, $I_{d}$ and $I_{q}$ are the direct and quadrature axis currents, $w_{e}$ are the electrical speed in rad/s, $\mathrm{p}$ is the pole-pair number, $L_{d}$ and $L_{q}$ are the inductance values of the direct and quadrature axes, $\Psi_{m}$ is the permanent magnet flux linkage and $R_{S}$ is the stator resistance.

d- and q- axis currents can be written by (6-8).

$$
\begin{aligned}
& \mathrm{I}_{\mathrm{d}}=-\mathrm{I}_{\mathrm{s}} * \sin \beta \\
& \mathrm{I}_{\mathrm{q}}=\mathrm{I}_{\mathrm{s}} * \cos \beta \\
& \left|\mathrm{I}_{\mathrm{s}}\right|=\sqrt{\mathrm{I}_{\mathrm{d}}{ }^{2}+\mathrm{I}_{\mathrm{q}}{ }^{2}}
\end{aligned}
$$


Substituting (3) into (6-8) one obtains;

$$
\frac{d T_{e}}{d \beta}=\frac{3 * p}{2}\left[-\Psi_{m} * I_{s} * \sin \beta+\left(L_{q}-L_{d}\right) * I_{s}{ }^{2} * \cos 2 \beta\right]
$$

The MTPA point is the point where the derivative of the torque value with respect to $\beta$ is 0 . The $\beta$ derivative of the (9) assuming that the machine parameters are constant is given as;

$$
\beta=\sin ^{-1}\left(\frac{-\Psi_{m}+\sqrt{\Psi_{m}^{2}+8 *\left(L_{q}-L_{d}\right)^{2} * I_{s}^{2}}}{4 *\left(L_{q}-L_{d}\right) * I_{s}}\right)
$$

Substituting (10) into (6-8) and solving for the d- axis current for MTPA point, (11) is obtained;

$$
I_{d}=\frac{\Psi_{m}}{2 *\left(L_{q}-L_{d}\right)}-\sqrt{\frac{\Psi_{m}{ }^{2}}{4 *\left(L_{q}-L_{d}\right)^{2}}+I_{q}{ }^{2}}
$$

Substituting (11) into torque equation [20];

$$
I_{q}^{M T P A}=\left(L_{q}-L_{d}\right)^{2} * I_{q}{ }^{4}+\frac{2 * T_{e}}{3 * p} * \Psi_{m} * I_{q}-\left(\frac{2 * T_{e}}{3 * p}\right)^{2}
$$

When the current $I_{q}$ is solved for the MTPA point, a 4th order non-linear equation is obtained. Newton Raphson method can be used to solve the higher order equation. Equations of the Newton Raphson method are given in (13) and (14).

$$
\begin{gathered}
I_{q}^{M T P A}(n+1)=I_{q}^{M T P A}(n)-\frac{\text { Function of } I_{q}^{M T P A}\left(I_{q}^{M T P A}(n)\right)}{\text { Derivative Function of } I_{q}^{M T P A}\left(I_{q}^{M T P A}(n)\right)} \\
\text { Derivative Function of } I_{q}^{M T P A}=4 *\left(L_{q}-L_{d}\right)^{2} * I_{q}^{3}+\frac{2 * T_{e}}{3 * p} * \Psi_{m}
\end{gathered}
$$

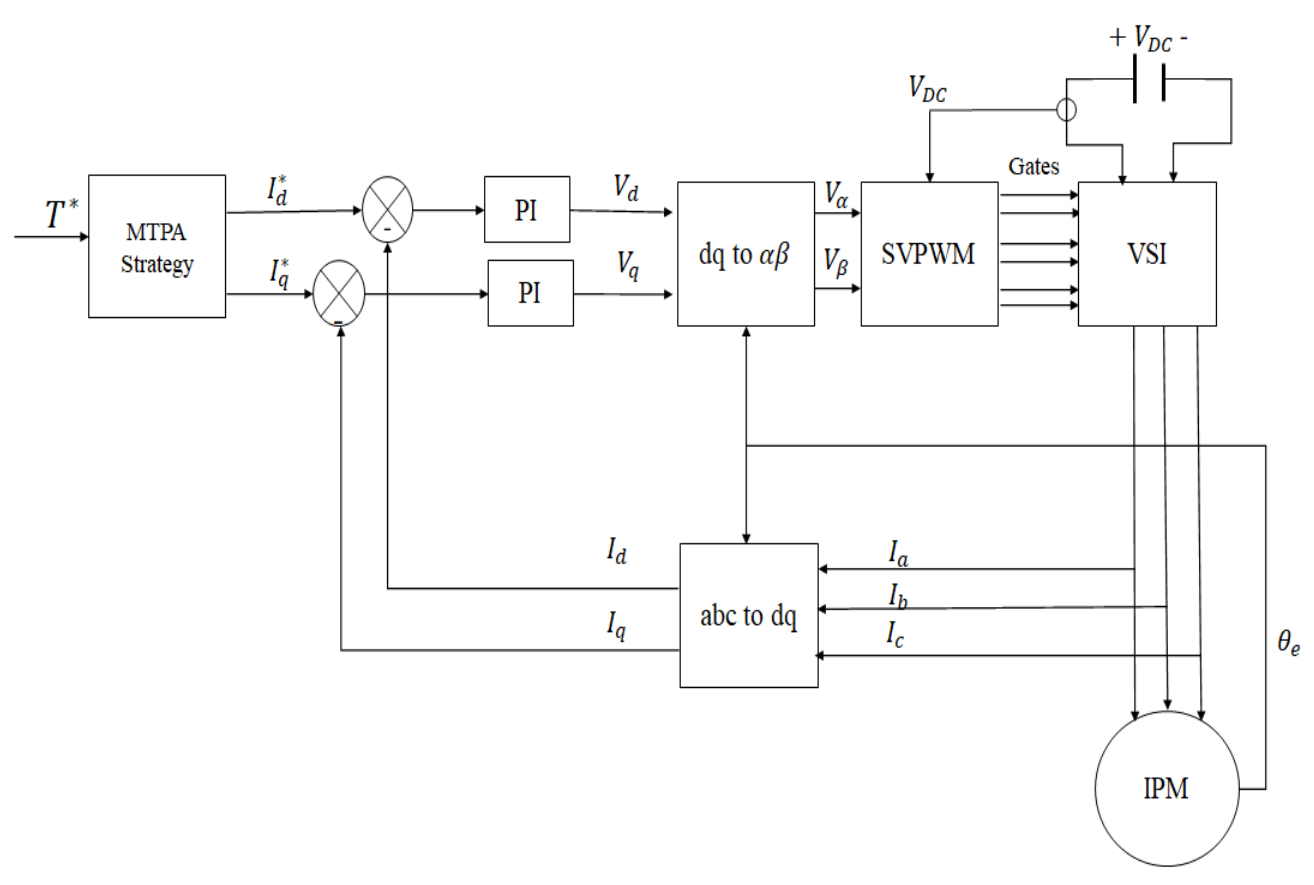

Figure 1. The Proposed Drive System Schematic 
To start the iteration, the initial value of the $I_{q}^{M T P A}$ must be determined. Since the magnet torque is effective at the beginning, the initial current value is as in (15).

$$
I_{q}^{M T P A}(0)=\frac{2 * T_{e}}{3 * p * \Psi_{m}}
$$

Substituting the value of $I_{q}^{M T P A}$ in the torque equation produces the reference value $I_{d}$ for MTPA operation.

$$
I_{d}^{M T P A}=\frac{2 * T_{e}}{3 * p * I_{q}^{M T P A} *\left(L_{d}-L_{q}\right)}-\frac{\Psi_{m}}{\left(L_{d}-L_{q}\right)}
$$

The proposed block diagram for the torque control of the IPM is shown in Figure 1. Since the comparison of $I_{d}=0$ control technique and MTPA is the subject of the study, in $I_{d}=0$ control technique, the reference current is 0 for the $d$-axis and the reference current for the q-axis is proportionally produced from the reference torque with the constant in (17).

$$
K_{t}=\frac{2}{3 * p * \varphi_{M}}
$$

It is important to note that (10)-(16) is correct under the assumption that the machine parameters are constant. The efficiency in practical applications may deviate slightly from the optimum, however, precise torque control can be achieved with the use of Newton-Raphson technique.

\subsection{Space Vector Pulse Width Modulation (SVPWM)}

Generally, two different PWM methods are commonly preferred in motor drive systems, namely, sinusoidal PWM (SPWM) and space vector PWM (SVPWM) [23, 24]. The first is SPWM technique and it is simple to implement. The second is the SVPWM technique, which is a good alternative to be used in motor drives with its superior features such as producing $\sim 15 \%$ more output voltage compared to SPWM technique, having less harmonics, and less switching losses [25]. In this study, SVPWM technique has been employed as it is superior.

Accordingly, as can be seen from Figure 1, demanded dq- axis voltages are transformed into the $\alpha \beta$ frame through the inverse Clarke transformation. Then the amplitude and angle of the reference vector consisting of voltage components in $\alpha \beta$ axis are determined. Considering the $360^{\circ}$ rotation angle, 6 sectors of each $60^{\circ}$ are formed. The sector in which the reference voltage vector lies is obtained from the angle value of the reference vector. Switching durations of the switches are determined according to the time expressions given by (18-20).

$$
\begin{gathered}
T_{1}=M * T_{S} * \sin \left(\left(n * \frac{\pi}{3}\right)-\theta\right) \\
T_{2}=M * T_{s} * \sin \left(\theta-(n-1) * \frac{\pi}{3}\right) \\
T_{0}=T_{S}-\left(T_{1}+T_{2}\right)
\end{gathered}
$$

$\theta, \mathrm{n}, M$ and $T_{s}$ are the angle of reference vector, sector number, modulation index and sampling time, respectively. Modulation index is given by (21) [26].

$$
M=\frac{\sqrt{3} * V_{r e f}}{V_{D C}}
$$




\section{Simulation Results}

In the control system, which is created by mathematical models, the switching frequency of the SVPWM technique is $5 \mathrm{kHz}$ in both $I_{d}=0$ control technique and the MTPA strategy. The results were obtained by running the simulation for 0.5 second. The limitation of using the battery capacity of 0.577 ratio, brought about by the SVPWM technique, is applied in the simulation in a way to prevent over-modulation. At speeds lower than the base speed, torque command value is changed with step functions up to the continuous torque value of the motor, and the accuracy of the control system is investigated. The front and rear image of the motor whose parameters are used in the simulations are given in Figure 2 and parameters of motor are listed in Table 1.
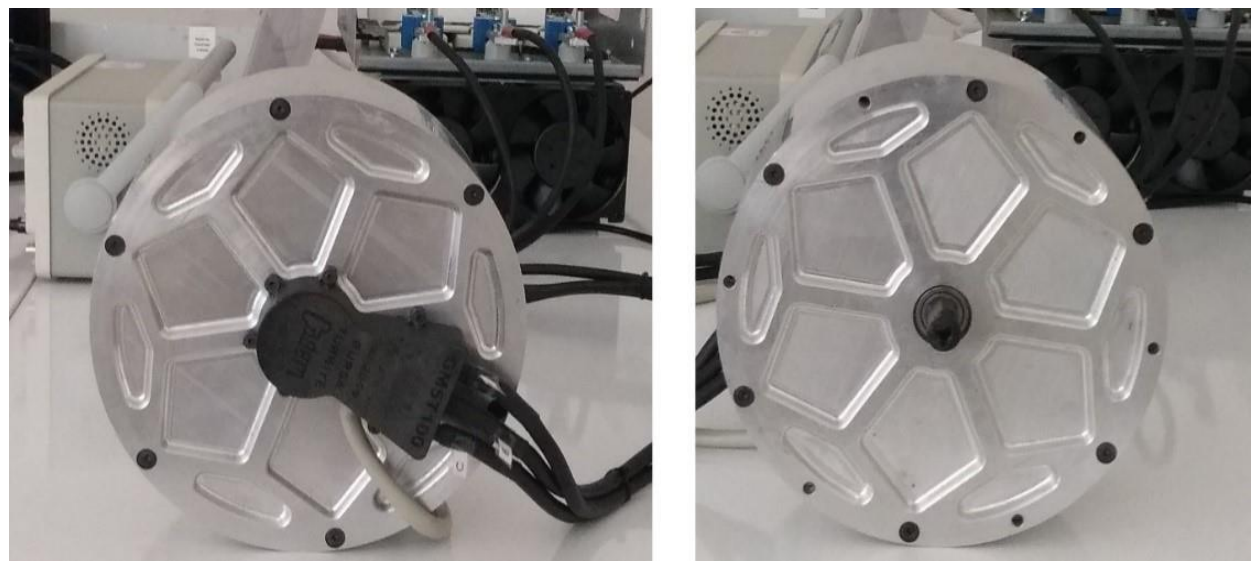

Figure 2. Motor view used in simulation

Table 1. Motor Parameters

\begin{tabular}{llc}
\hline Motor Type & \multicolumn{2}{l}{ Interior Permanent Magnet Synchronous Motor } \\
\hline Phase Number/ Pole Number & $3 / 8$ & \\
Nominal Speed & $2500 \mathrm{rpm}$ & @ 120 V DC \\
Continuous Torque & $15.7 \mathrm{~N} . \mathrm{m}$ & @ $51.6 \mathrm{~A} \mathrm{rms}$ \\
Continuous Power & $4.1 \mathrm{~kW}$ & \\
Input Voltage Range & $12 \mathrm{~V}-600 \mathrm{~V}$ \\
Nominal d-Axes Inductance & $0.282 \mathrm{mH}$ & \\
Nominal q-Axes Inductance & $0.0828 \mathrm{mH}$ & \\
Nominal Stator Flux Magnitude & $0.0182 \mathrm{Weber}$ & \\
Nominal Phase Resistance & $0.0463 \mathrm{ohm}$ & \\
Inertia & $0.0072 \mathrm{~kg} \cdot \mathrm{m}^{2}$ & \\
\hline
\end{tabular}

Case 1: Variable Torque and Constant Speed Comparison

By keeping the speed value at $1000 \mathrm{rpm}$, the torque value has been changed from 3 N.m with step functions up to the continuous torque value of the motor $(15.7$ N.m) as shown in Figure 3. Control systems created with both the $I_{d}=0$ control technique and the MTPA strategy can follow the torque. However, the required current magnitude to produce commanded torque in the control system operating with the $I_{d}=0$ control technique is significantly higher than the current value in the control system controlled by the MTPA strategy. In other words, $I_{d}=0$ control technique consumes more power by drawing more current from the battery to track the reference torque. As can be seen from Figure 3, when 15.7 N.m torque is demanded from the system, MTPA strategy produces 
reference torque with $48 \mathrm{~A}$ current magnitude, while the control system operating with $I_{d}=0$ control technique requires 72 A current magnitude.
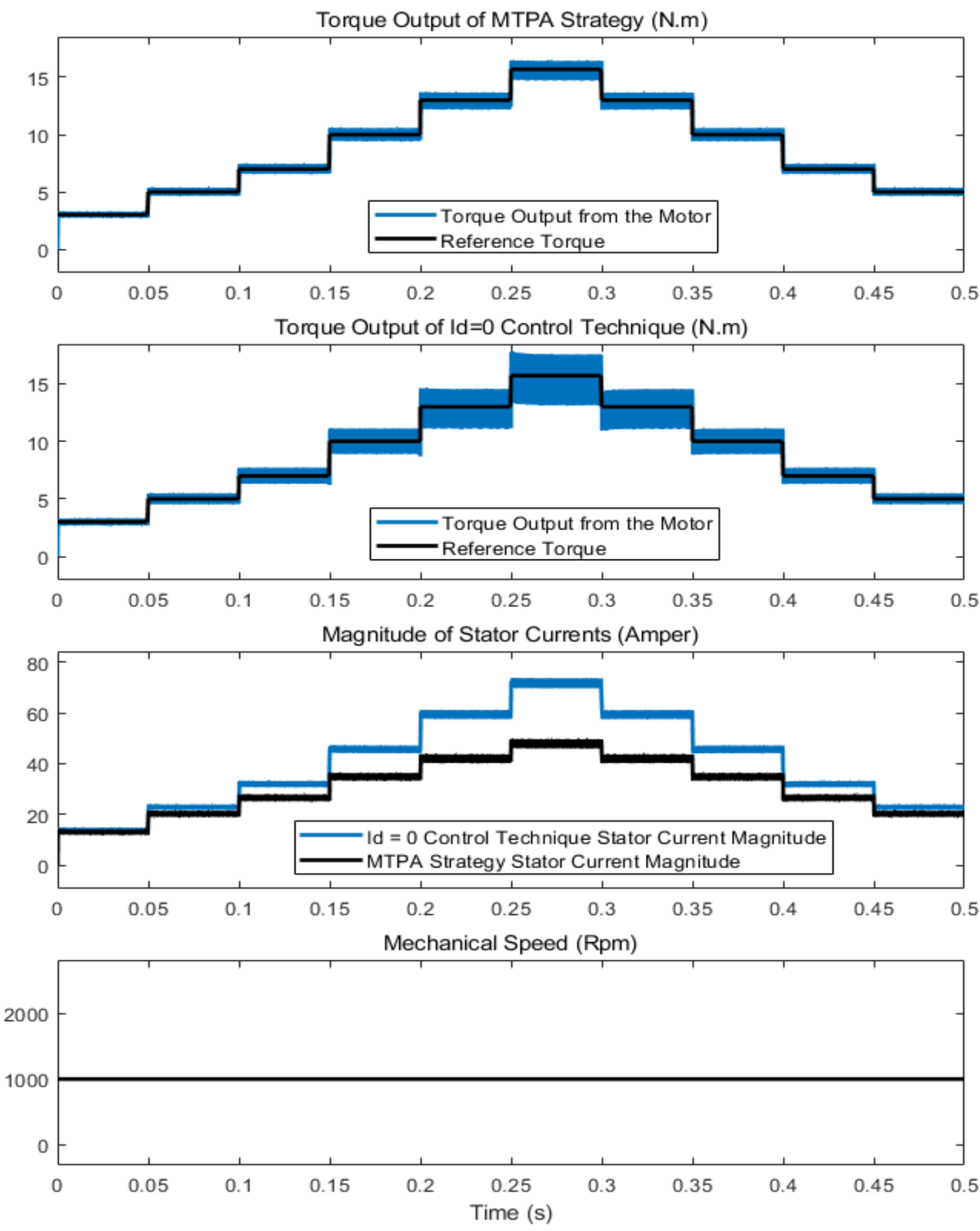

Figure 3. Torque and Current Outputs with the Two Control Strategies

Case 2: Variable Speed and Constant Torque Comparison

While demanding a constant torque value from the motor, the mechanical speed is increased with a ramp function from $0 \mathrm{rpm}$ to $2000 \mathrm{rpm}$ as shown in Figure 4. It is seen that the conventional $I_{d}=0$ control technique is not able to generate demanded torque above $1340 \mathrm{rpm}$ speed value while the torque production is successfully achieved with the MTPA control strategy. 
$I_{d}=0$ control technique reaches the system voltage limits at approximately $1340 \mathrm{rpm}$ in the drive system applied. To generate the demanded torque from the motor as in MTPA drive system, the battery voltage level must be increased. As can be seen from Figure 5, when the $187 \mathrm{~V}$ battery voltage level is applied, the $I_{d}=0$ controlled drive system can produce the command torque. One can deduce from the results that the torque ripple increases dramatically with the increasing stator current magnitude. Hence, accurate control strategy not only provides the demanded value but improves the output torque quality as well.
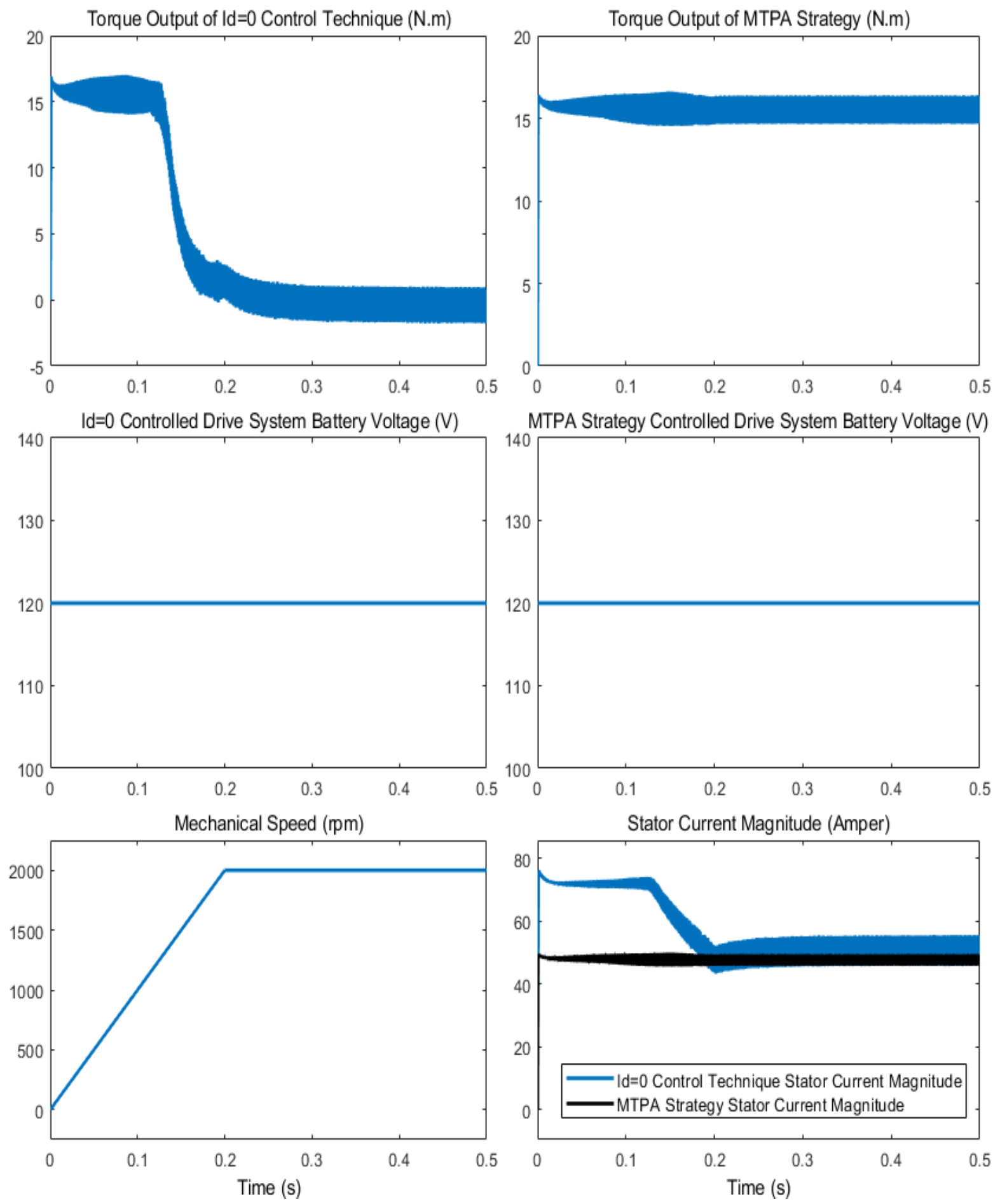

Figure 4. Variable Speed Comparison 

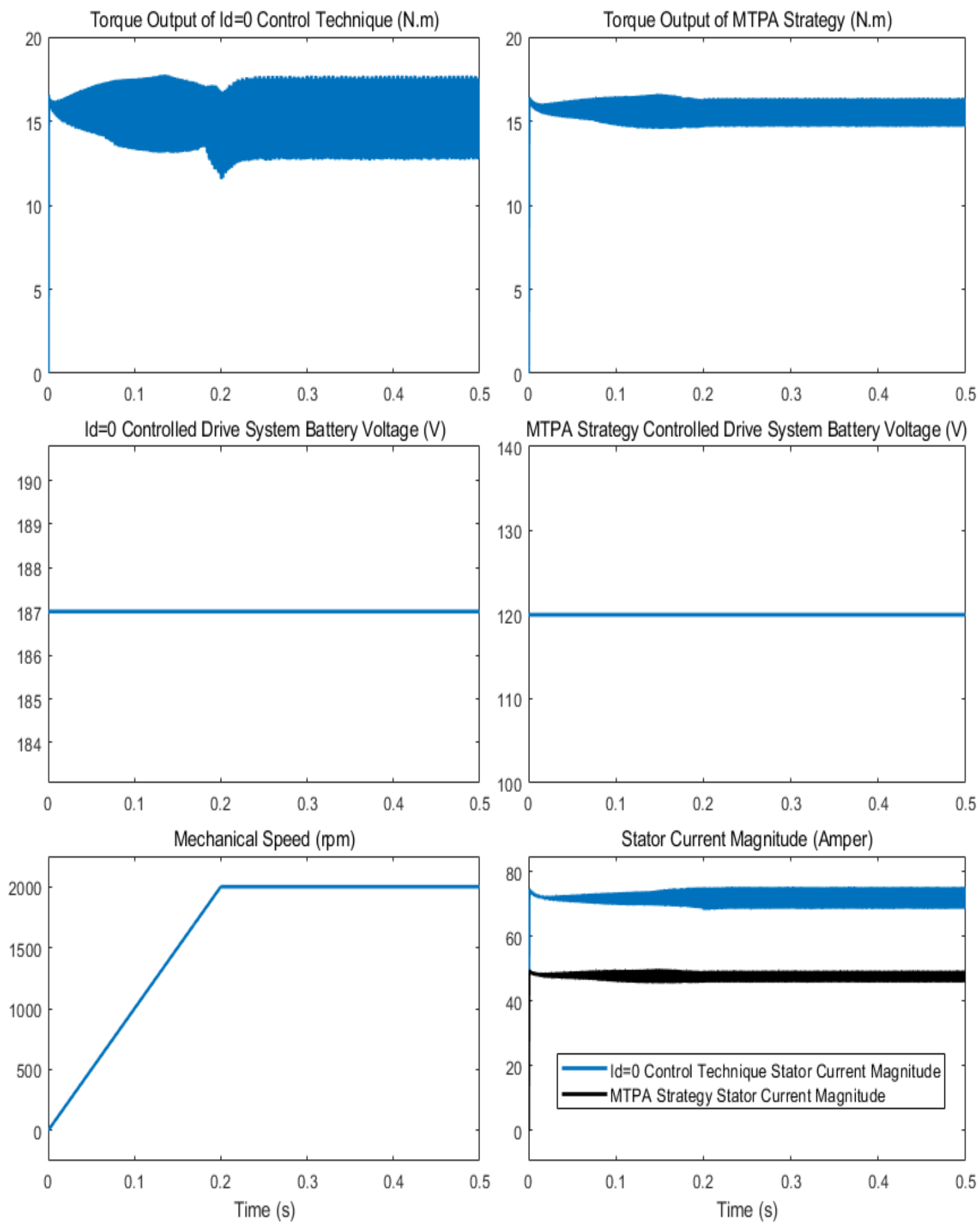

Figure 5. Outputs on Correction of Battery Voltage

\section{Conclusion}

It has been proven in this paper that the conventional $I_{d}=0$ control technique does not provide optimum efficiency for each PMSM type due to the different rotor structures in the design of PMSMs. It has been shown that IPMs with saliency in their rotor are more efficient with the MTPA strategy compared to the $I_{d}=0$ control technique. Additionally, since $I_{d}=0$ controlled system does not produce the demanded torque with the minimized stator current magnitude, the system reaches the voltage limitation at a lower speed. Hence, rated torque production at the base speed can be obtained 
with reduced battery voltage level if MTPA strategy is adopted. Moreover, the torque ripple with the MTPA control has been reduced significantly as the torque production can be achieved with the minimized stator current magnitude. All in all, accurate MTPA control adoption improves output torque quality, increases efficiency, extends drive range, and reduces the battery size for the traction applications. The two control strategies have been compared in the constant torque region (MTPA control) and the comparisons of the two strategies in the extended speed region (Constant Power Region, Field-Weakening control) would be further studied as future research.

\section{Acknowledgment}

This study has been supported by the Scientific and Technological Research Council of Turkey (TUBITAK) through the Scientific and Technological Research Projects Funding Program (1001) with a project numbered as $118 \mathrm{E} 858$.

\section{Authors' Contributions}

This study was produced from the master's thesis prepared by Osman Emre ÖZÇİFLİKÇİ under the supervision of Serkan BAHÇECI and Mikail KOÇ, in the Department of Electrical- Electronics Engineering at Erciyes University and Ahi Evran University, respectively. Serkan BAHÇECI and Mikail KOÇ determined the main idea of the study and carried out paper revisions. Obtaining the simulation results and paper writing was carried out by Osman Emre ÖZÇİFLİKÇİ.

\section{Competing Interests}

The authors declare that they have no competing interests.

\section{References}

[1]. Mahapatra U., "Energy Storages and Technologies for Electric Vehicle," 2021 Innovations in Energy Management and Renewable Resources(52042), Kolkata, India, pp. 1-3, (2021).

[2]. Kunt M.A., "Advisor Based Modeling of the Effect of Rolling Resistance on Regenerative Braking in All-Electric Passenger Cars", El-Cezeri, 2019. 6(3): p. 847-855.

[3]. Bayraktar M , Y.E., "Constant Current/Voltage Charging of A 250W E-Bike with Wireless Power Transfer", El-Cezeri, 2020. 7(1): p. 189-197.

[4]. Mohd Ab Halim M , S.E., "Permanent Magnet Flux Switching Torque Performance Indicator" El-Cezeri, 2021.8 (2): p. 582-591.

[5]. Koç M., "Efficiency Optimised Control Of Interior Mounted Permanent Magnet Machines For Electric Vehicle Traction". PhD Thesis, Department of Electronic and Electrical Engineering University of Sheffield, (2016).

[6]. Wang Z., et al., "Challenges Faced by Electric Vehicle Motors and Their Solutions", IEEE Access, 2021. 9: p. 5228-5249.

[7]. Finken T., Felden M., and Hameyer K., "Comparison and design of different electrical machine types regarding their applicability in hybrid electrical vehicles". 18th International Conference on Electrical Machines, Vilamoura, Portugal, pp. 1-5,(2008).

[8]. Dong J., et al., "Comparative Study of Surface-Mounted and Interior Permanent-Magnet Motors for High-Speed Applications". IEEE Transactions on Applied Superconductivity, 2016. 26(4): p. 1-4.

[9]. Tiecheng S., et al. "Design of PMSM vector control system based on TMS320F2812 DSP". Proceedings of The 7th International Power Electronics and Motion Control Conference, Harbin, China, pp. 2602-2606, (2012).

[10]. Yan G. "Simulation for the Vector Control Algorithm of Permanent Magnet Synchronous Motor", 2015 7th International Conference on Intelligent Human-Machine Systems and Cybernetics, Hangzhou, China, pp. 456-459, (2015). 
[11]. Yu L., et al. "Simulation of PMSM field-oriented control based on SVPWM". 2017 29th Chinese Control And Decision Conference (CCDC), Chongqing, China, pp. 7407-7411,(2017).

[12]. Dwivedi S.K., Laursen M., and Hansen S. "Voltage vector based control for PMSM in industry applications". 2010 IEEE International Symposium on Industrial Electronics, Bari, Italy, pp. 3845-3850, (2010).

[13]. Sun T., Koç M., and Wang J., "MTPA Control of IPMSM Drives Based on Virtual Signal Injection Considering Machine Parameter Variations". IEEE Transactions on Industrial Electronics, 2018. 65(8): p. 6089-6098.

[14]. Gubae R., et al. "A MTPA control scheme for an IPM synchronous motor considering magnet flux variation caused by temperature" Nineteenth Annual IEEE Applied Power Electronics Conference and Exposition, Anaheim, CA, USA, pp. 1617-1621 Vol.3, (2004).

[15]. Morimoto S., et al., "Servo drive system and control characteristics of salient pole permanent magnet synchronous motor". IEEE Transactions on Industry Applications, 1993. 29(2): p. 338343.

[16]. Yang N., et al. "Interior permanent magnet synchronous motor control for electric vehicle using look-up table", Proceedings of The 7th International Power Electronics and Motion Control Conference, Harbin, China pp. 1015-1019, (2012).

[17]. Kim S., et al. "Parameter independent maximum torque per ampere (MTPA) control of IPM machine based on signal injection" 2010 Twenty-Fifth Annual IEEE Applied Power Electronics Conference and Exposition (APEC), Palm Springs, CA, USA, pp. 103-108, (2010).

[18]. Chen Z., et al., "An Accurate Virtual Signal Injection Control for IPMSM With Improved Torque Output and Widen Speed Region", IEEE Transactions on Power Electronics, 2021. 36(2): p. 1941-1953.

[19]. Jiang H., Zhang Y., and Yang H. "An Improved Virtual Signal Injection Control of MTPA for an IPMSM" 2020 IEEE Energy Conversion Congress and Exposition (ECCE), Detroit, MI, USA pp. 2696-2700, (2020).

[20]. Hoang K.D., et al. "Feed-forward torque control of interior permanent magnet brushless AC drive for traction applications" 2013 International Electric Machines \& Drives Conference, Chicago, IL, USA, pp. 152-159, (2013).

[21]. Shoudao H., et al. "Maximum torque per ampere and flux-weakening control for PMSM based on curve fitting" 2010 IEEE Vehicle Power and Propulsion Conference Lille, France , pp. 1-5, (2010).

[22]. Wang S., et al. "A Novel Newton-Raphson-Based Searching Method for the MTPA Control of Pmasynrm Considering Magnetic and Cross Saturation" 2018 XIII International Conference on Electrical Machines (ICEM) Alexandroupoli, Greece,pp. 1360-1366, (2018).

[23]. Ping L. and Lan C. "Study on controlling and simulation of drive system for permanent magnet synchronous motor in electrical vehicle" 2012 Power Engineering and Automation Conference, Wuhan, China, pp. 1-4, (2012).

[24]. Waghmare M.K. and Patil S.V. "Speed Control Strategy of Permanent Magnet Synchronous Motor Drive Using SPWM Technique" 2019 4th International Conference on Recent Trends on Electronics, Information, Communication \& Technology (RTEICT), Bangalore, India, pp. 1328-1332, (2019).

[25]. Rathnakumar D., LakshmanaPerumal J., and Srinivasan T. "A new software implementation of space vector PWM" Proceedings. IEEE SoutheastCon, Ft. Lauderdale, FL, USA, pp. 131-136, (2005).

[26]. Srivastava S. and Chaudhari M.A. "Comparison of SVPWM and SPWM Schemes for NPC Multilevel Inverter" 2020 IEEE International Students' Conference on Electrical,Electronics and Computer Science (SCEECS), Bhopal, India, pp. 1-6 ,(2020). 